Article

\title{
Industry 4.0 Implementation in B2B Companies: Cross-Country Empirical Evidence on Digital Transformation in the CEE Region
}

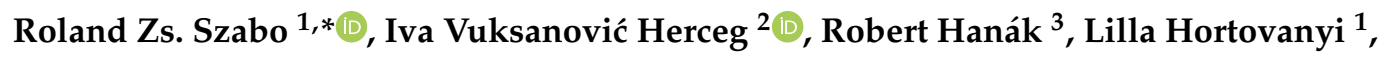 \\ Anita Romanová ${ }^{3}$, Marian Mocan ${ }^{4}\left(\mathbb{D}\right.$ and Dragan Djuričin ${ }^{2}$ \\ 1 Strategic Management Department, Corvinus University of Budapest, 1093 Budapest, Hungary; \\ lilla.hortovanyi@gmail.com \\ 2 Faculty of Economics, University of Belgrade, 11000 Belgrade, Serbia; iva.vuksanovic@ekof.bg.ac.rs (I.V.H.); \\ dragan.djuricin@ekof.bg.ac.rs (D.D.) \\ 3 Faculty of Business Management, University of Economics in Bratislava, 85235 Bratislava, Slovakia; \\ robert.hanak@euba.sk (R.H.); anita.romanova@euba.sk (A.R.) \\ 4 Faculty of Management in Production and Transportation, Politehnica University Timisoara, \\ 300191 Timisoara, Romania; marian.mocan@upt.ro \\ * Correspondence: szabozsoltroland@yahoo.com; Tel.: +36-30-4453744
}

Received: 26 October 2020; Accepted: 8 November 2020; Published: 16 November 2020

\begin{abstract}
Previous research has pointed out that Industry 4.0 will lead to more sustainable production; however, it may have profound effects on European competitiveness. Today, firms in the CEE countries face a limited scope for continued economic expansion, and hence there is a growing pressure on them to move upward in the global value chain by investing heavily in advanced technology. Consequently, the authors argue that B2B firms from the CEE countries can have a massive impact on Europe's long-term competitiveness by reversing the effect of digital transformation due to their strong interdependencies on other European economies. Therefore, in a cross-country survey, research data were collected $(n=302)$ about the driving forces, barriers, and role of stakeholders in the implementation of digital transformations. The authors found that some technologies are implemented much more frequently compared to others, with some indication for country specialization. The leading driving force is customer satisfaction followed by productivity and financial motives. Shortage of skilled human resources and high implementation costs are the main barriers. The firms tend to rely on universities and research centers, while the government is perceived only as a financial provider. The results are also informative for practitioners and policymakers-providing them with benchmarks.
\end{abstract}

Keywords: Industry 4.0; digital transformation; B2B; driving force; barrier; stakeholders; value chain

\section{Introduction}

A study by CEDEFOP [1] found that hiring difficulties related to shortages of highly skilled staff constrained firm productivity and the adoption of innovative technologies as well as new ways of organizing work. An increasing number of firms have reported experiencing genuine skills shortages, despite their willingness to pay higher wages. The firms most likely to be affected are the ones that demand more considerable expertise and new skills from their workforce [2]. Technological progress and, in particular, artificial intelligence $(\mathrm{AI})$, robotization and automation are compounding this problem, while also having profound direct effects of their own on European countries. The new digital technologies lower entry barriers for new competitors, so incumbent firms need to respond 
and reposition themselves quickly to meet disruptive challenges. Firms are forced to rethink their processes and invest in digital technologies.

Measuring trade in value-added terms sheds new light on today's trade reality, where competition is not between nations, but between firms. Competitiveness in a world of global value chains (GVCs) means that firms as members of a value chain must increase either their technological content or improve their existing inefficiencies. However, if only certain actors in the GVCs adopt superior technologies, then high inequalities are projected [3]. A value chain is only as strong as its weakest link, and the competitiveness of an industry may be lowered if it relies on inputs from less competitive suppliers.

The challenges of particular importance are also those related to the United Nations' Sustainable Development Goals as well as to the European Union's aims. As a part of a larger and pervading phenomenon, however, it is also expected that the digital transformation of businesses will lead to more sustainable production $[4,5]$. Industry 4.0 has been proven to contribute to an overall efficiency increase (i.e., [6,7]) in the form of material consumption, waste reduction, and adaptive working environments [8-12].

Nevertheless, the European Union is characterized by interconnected economies. Formerly, the delocalization of production phases of European firms in the CEE countries was the engine behind the economic growth in the region [13]. Today, Backé et al. [14] argue that the CEE countries face a somewhat limited scope for continued economic expansion, because their current growth model is mostly based on assembly and imitation. There is therefore a growing pressure on these firms from the CEE countries to move upward in the global value chain by investing heavily in advanced technology. Consequently, the authors argue that B2B firms from the CEE countries can have a massive impact on Europe's long-term competitiveness by reversing the effect of digitalization due to their strong interdependencies on other European economies.

Thus, it is no surprise that digital transformation has attracted growing scholarly attention. Previous studies often approach it as a technology challenge focusing on the adoption of different technologies [15-18]. Despite this research stream having been proven to be very informative, the holistic view of company-wide digital transformation, however, is absent [19]. The research regarding the digital transformation and its implementation is still constrained in relevance for practice $[20,21]$. Empirical work on implementation focus areas, driving forces, barriers and managerial expectations supporting digital transformations would not only contribute significantly to the literature but also guide practitioners on how to prepare and direct resource investments strategically [22]. Second, previous studies have been conducted on country level data [23-27] ignoring the context and relevance of the value chain systems [28] as well as their influence on Europe's global industrial position $[29,30]$, with special relevance to the CEE countries.

To bridge these research gaps, the present study aims to explore how CEOs and other members of top management teams perceive the main driving forces and barriers for the most common Industry 4.0 technologies/focus areas. The research is conducted on a unique set of primary data, based on cross-country analysis within the CEE region. Hence, its main contribution is that it provides an insight, not only for practitioners but also for policymakers, on today's burning challenge of how to enable and facilitate the digital transformation of B2B firms located in lower-income member states of the European Union. This is crucial information, as addressing the right antecedents of digital transformation, in particular the drivers and barriers of its implementation, can enable the firms not only to succeed but to move upward in the global value chain. This in turn contributes to an increase in the competitiveness of both the entire industry and Europe's global industrial position. Furthermore, the paper offers reliable insight into the validity of the skill shortage assumption in the CEE region.

Our study makes several contributions to current knowledge. First, our quantitative study, using an unlabeled bipolar semantic differential scale, provides evidence of the relative importance of the most important driving forces and barriers of Industry 4.0 implementation on a sample of $302 \mathrm{~B} 2 \mathrm{~B}$ firms from four countries in the CEE region, namely Hungary, Romania, Serbia and Slovakia. 
The cross-country analysis in itself is novel. According to our knowledge, only a very few attempts have been made to conduct a quantitative study in multiple countries (e.g., [31]). Second, our research highlights the implementation status of key technologies on which Industry 4.0 is based. Third, it sheds light on how key stakeholders in the Industry 4.0 ecosystem such as universities, governments and users or suppliers are perceived in their contribution when companies active in Industry 4.0 need help. Fourth, these findings are particularly useful for the practitioners interested in effective Industry 4.0 implementation as a benchmarking, as well as for policymakers responsible for the design and development of effective policies that not only remove barriers but also address the real drivers of digitalization. Fifth, the perspective of stakeholders reveals that some stakeholders (government and suppliers) are currently unable to sufficiently provide expected help to the companies, and hence they turn to other users of Industry 4.0 and universities for help.

The paper is structured as follows. After the introduction, the second part is dedicated to the literature review, which the main research questions are based on. In particular, the analysis focuses on Industry 4.0 focus areas, driving forces and barriers of Industry 4.0 implementation, as well as key stakeholders' support. The third part provides more details on the survey design, the measurement methods, and the sample. The results of the survey are given in the fourth part followed by a more extensive discussion in the fifth part. The last part contains the most important conclusions, contributions, and limitations of the paper.

\section{Literature Review}

\subsection{Industry 4.0 Focus Areas}

$\mathrm{Xu}$ [32] describes Industry 4.0 as a current trend of the manufacturing industry characterized by high level of automation, industrial integration, and industrial information integration. It includes enabling technologies/focus areas such as digitalization, Internet of Things, cyber-physical systems, automation of production processes, cloud computing, big data analytics and many others. What technologies are related with Industry 4.0 is a matter of intensive scientific discussion, where some authors identified more than 1000 different technologies associated with this trend [18], making them very difficult to manage [33]. Despite being strongly interrelated, in a technical and technological sense they are de facto separated into specific technical subsystems, which are implemented in the companies as relatively independent. Therefore, there is no technological need to implement them all, or at the same time, they could be implemented separately, or in a parallel way. As they are very costly and human resource consuming systems, organizations face the problem of deciding which of these technologies to implement first.

Another factor influencing Industry 4.0 technologies' implementation is their level of practical maturity. Apart from the first experimenting pioneers, companies in large numbers will implement them only in the case that the benefits are clear, economically verified and technically proven. Automatization of production processes is, for example, a technology with a decades-long history of systematic small steps of improvement, of which manufacturing companies are very well aware. On the other side, cyber-physical systems or Internet of Things are much younger and based on a unique combination of technologies (i.e., combinatorial innovation), which makes them disruptive and still embryonic [34]. Relative technological independency, different levels of practical maturity, and high cost of implementation make companies selective in applying these technologies. To describe how Industry 4.0 is implemented and spread in central European countries, the authors investigate the level of specific technologies implementation. Therefore, our first research question is as follows:

RQ1: What are the most common Industry 4.0 focus areas/technologies?

\subsection{Driving Forces and Barriers of Industry 4.0}

Driving forces encouraging companies to implement Industry 4.0 arise first from internal natural evolution of key technologies' innovations and from strong external trends, which we consider as more 
influential. In a globalized world, with more efficient and faster transporting routes, more competitors have access to the same markets making competition for customers even more intense. Growing competition forces companies to apply various strategies tackling all aspects of company processes in attempts to survive [35].

Kamble and colleagues [36] carried out a review study on how smart technologies of Industry 4.0 deliver positive effects on various performance dimensions, namely costs, quality, flexibility, time, integration, optimized productivity, real-time diagnosis and prognosis, computing, social and ecological sustainability. These dimensions are based on specific indicators such as lower material and energy consumption [9-11], lower human labor demands, higher efficiency in the production process [7] with higher quality [37], higher flexibility, time saving and hundreds of others. These specific and partial indicators are finally transformed towards improved total performance [38]. However, internal organizational processes are not the only drivers of Industry 4.0. External factors such as public image may play a role. Customers, employees, and managers may have expectations about how their products should be manufactured. Despite serious efforts being made to theoretically identify various driving forces, little is known about how companies active in Industry 4.0 really interpret them. Which of them are considered by top executive officers more important than others? Therefore, one of the goals of this paper is to not only identify main driving forces, but also to describe how top executive officers and CEOs rank them in terms of their relative importance.

On the other side, there are clear barriers related to the implementation of Industry 4.0. Raj et al. [39] conclude, based on extensive literature research, that barriers remain largely unexplored despite the serious efforts of many research teams. Several studies have analyzed barriers from the theoretical point of view $[4,35,40-42]$, but there are very few empirical studies investigating these barriers from the empirical side $[23,24,43-47]$. Therefore, our study aims to fill the gap and provide insight into how corporate executives interpret the main barriers of Industry 4.0. Apart from identifying the most important barriers to Industry 4.0 implementation, the aim of this research is also to investigate which of them are the most severe and which are less significant. Therefore, the second research question is:

RQ2: What are the main driving forces and barriers of Industry 4.0?

\subsection{Industry 4.0 Ecosystem/Stakeholder Support}

Industry 4.0 is a new technological phenomenon with potentially enormous impact, not only in its direct field of implementation - manufacturing — but on many areas of broad social activities and structure [48-52]. Companies implementing or already using Industry 4.0 technologies face a myriad of problems typical for any implementer of new and highly disturbing innovations into successful company praxis. All these problems they face could be organized into four summary categories: technological/technical, economic/financial, human resources and management/leadership issues. Though very distinct in their origin and structure, nevertheless each can affect the way Industry 4.0 technologies are implemented, since companies do not have all resources needed for successfully solving each simultaneously, and therefore outside help is often required. Reischauer [53] claims that this process of innovation encompasses three main players: business, politics, and academia. We categorized them into the following four key external types of organizations capable of providing professional support and help to the companies using Industry 4.0 technologies: (1) government; (2) university and research institutes; (3) suppliers of Industry 4.0 and (4) users of Industry 4.0.

As a technological revolution, based on large spectrums of relatively independent innovations, it is unconditionally related with innovation generators, which are research institutes and universities. They are the first stakeholder in the complex ecosystem. Not only are universities expected to contribute to the relevant pool of skilled and competent workforce [54,55], they are also believed to play a pivotal role in easing cultural and social transitions required for successful Industry 4.0 implementation [56]. Several authors [57-59] have underlined the importance of knowledge transfer between industries and educational institutions for attaining advanced manufacturing education (concept Education 4.0). 
Governments recognized Industry 4.0's importance quickly due to the positive economic impact, which led them to support this new revolution. That is why governments are assumed to be the second key stakeholder.

The third group, the suppliers of Industry 4.0, are the companies that supply cutting edge products and services that are driving the digital transformation. They are either the suppliers of building blocks that are used to create the factory of the future solutions, where sensors, software, and hardware are connected. Alternatively, they are suppliers of other technologies that can be deployed independently or alongside these building blocks. For example, Upskill, the developer of the augmented reality application platform, as well as Cognex, the developer of machine vision solutions, are both leading suppliers of Industry 4.0.

The fourth group includes the users of Industry 4.0. The users are, in fact, the customers, the companies that purchase Industry 4.0 solutions and building blocks. For example, the development of intelligent solutions is of great importance at Thyssenkrupp. Hence, the company has invested heavily in mobile solutions for smart interaction with their customers. In some additional cases, the supplier of Industry 4.0 is also the user of other Industry 4.0 solutions. This is the case of Siemens and ABB.

Due to its magnitude and its high level of novelty and risks, the cooperation between independent companies (both between suppliers and users, and users with other users) is also very likely.

Organizations using/implementing Industry 4.0 face many problems, but little is known about the specific demands towards particular stakeholders. For example, which stakeholders are expected to help when needing help solving technological issues? Do companies expect to share costs with universities/research centers? Are there any expectations about human resources towards the government? These and many other questions related to expectations made by companies active in Industry 4.0 towards stakeholders are largely unknown. Therefore, we set our third research question as follows:

RQ: What do firms active in Industry 4.0 expect from other members/stakeholders of the Industry 4.0 ecosystem?

\section{Methods}

\subsection{Research Design}

Based on previously elaborated research questions, the authors conceptualized the inquiry in several parts. Apart from general information about the interviewee and the company, the inquiry consisted of three main parts. The first part was dedicated to identification of the most important areas (practices) of Industry 4.0, the most significant driving forces, and barriers to the implementation of Industry 4.0. The aim of the second part was to identify the perceived level of digital maturity of the analyzed companies in general, as well as from the perspective of different value chain activities and resources. The third part was used to analyze the actors and stakeholders of Industry 4.0, their relative importance and expected support.

The primary data were gathered from B2B firms in Hungary, Romania, Serbia, and Slovakia, which are countries with a shared history and similar economic structure. Being part of the Habsburg Monarchy, these countries have hundreds of years of experience coexisting together under the same state entity. This long-term coexistence has had many effects, for example, the structure of these economies is mostly compatible with one another as they have similar levels of business dynamism and innovation capability, resulting in the same level of competitiveness [60].

In addition, previous research has argued that B2B firms face much less stakeholder pressure due to their lack of proximity to consumers and end-users; hence, these firms are slower to take up digital transformation initiatives compared to the consumer-facing B2C firms [61]). Consequently, the authors' intention was to study closely those B2B firms that were already active in digital transformation. Since the phenomenon is very new, and we still lack empirical data, the size of the population is assumed to be small. 
Moreover, the analysis was conducted on a homogenous sample of companies active in Industry 4.0 therefore reducing the variability of the data [62]. Secondly, according to the central limit theorem, a sample size of 30 is considered sufficient for most distributions. In our case, for Romania, we have a sample size of 29 companies, but for all other countries we have more than twice as many and the total sample size is ten times higher than recommended. Thirdly, high statistical significance we reported is an indicator of robust and valid results.

Consequently, the sample of 302 firms is representative of the population of Industry 4.0 active, $\mathrm{B} 2 \mathrm{~B}$ firms in the CEE region.

\subsection{Measurement of Driving Forces and Barriers of Industry 4.0}

The driving forces and the barriers of Industry 4.0 have been measured on an unlabeled bipolar semantic differential scale [63] with seven points, where the middle point represents the indifference between two factors. There are six main categories of driving forces for Industry 4.0; (1) human resources [20,42,64-66], (2) financial resources and profitability [20,65-74], (3) market conditions and competitors [35,40,73-79], (4) management expectations, (5) productivity and efficiency $[5,20,65-69,71-74,80]$, and (6) customer satisfaction [81,82]. Within the main categories, a total of 30 items were examined (Table 1). There are five main categories of barriers for Industry 4.0; (1) human resources [16,42,52]; (2) financial resources and profitability [20,42,74,83]; (3) management reality $[42,45,72],(4)$ organizational factors $[40,42,45,69]$, and (5) technological and process integration, cooperation $[40,42,45,69]$. Within the main categories, a total of 17 items were examined (Table 1 ).

Table 1. Driving forces and barriers of Industry 4.0.

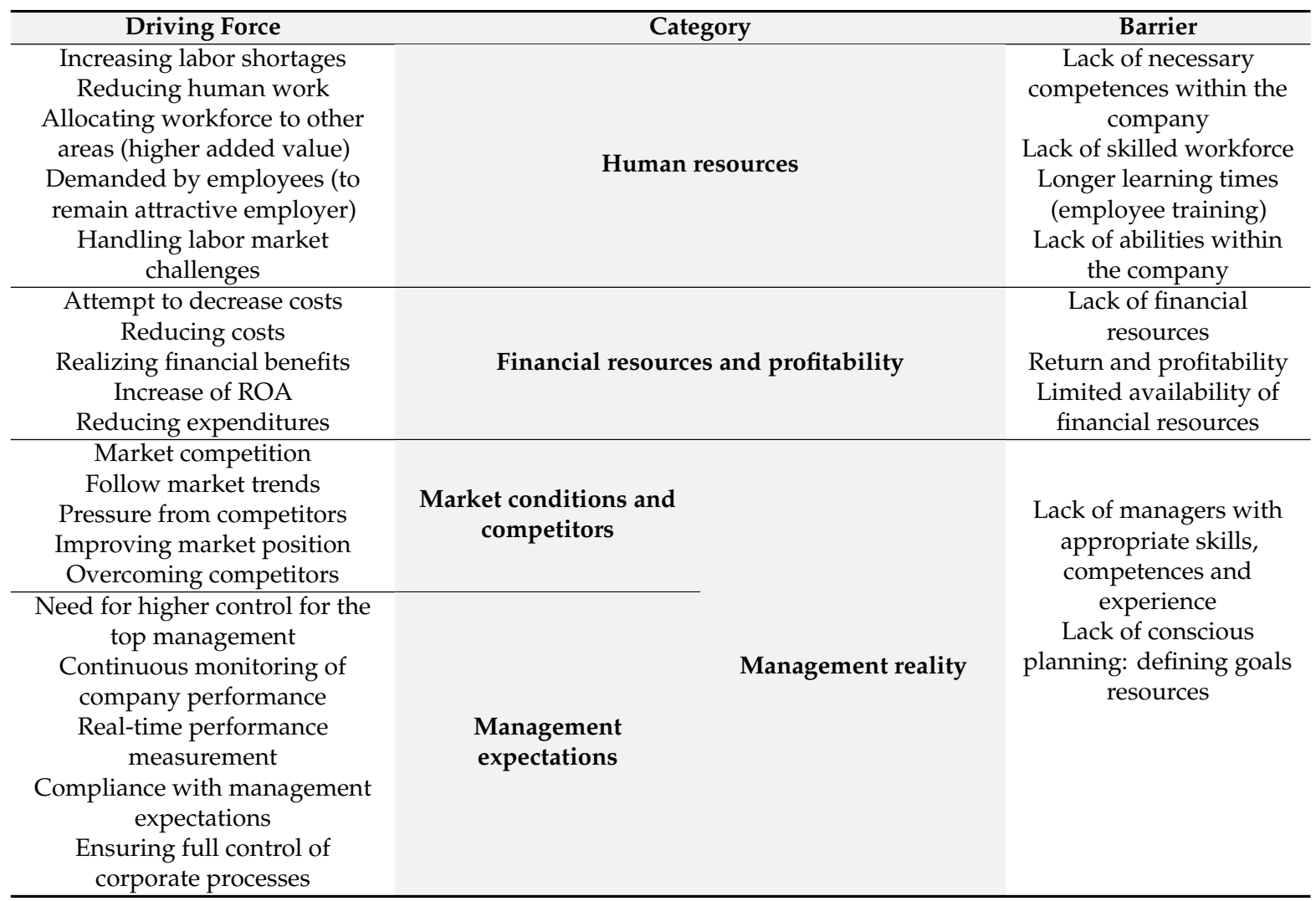


Table 1. Cont.

\begin{tabular}{|c|c|c|c|}
\hline Driving Force & \multicolumn{2}{|c|}{ Category } & Barrier \\
\hline $\begin{array}{l}\text { Reducing the error rate } \\
\text { Improving lead times } \\
\text { (compliance with market } \\
\text { conditions) } \\
\text { Efficiency improvement } \\
\text { Ensuring reliable operation } \\
\text { Less stoppages in production }\end{array}$ & $\begin{array}{l}\text { Productivity and } \\
\text { efficiency }\end{array}$ & Organizational factors & $\begin{array}{c}\text { Inadequate } \\
\text { organizational structure } \\
\text { Resistance by employees } \\
\text { Inadequate process } \\
\text { organization } \\
\text { Resistance from middle } \\
\text { management }\end{array}$ \\
\hline $\begin{array}{c}\text { Demanded by } \\
\text { customers/partners } \\
\text { Improving customer satisfaction } \\
\text { Demand for quality } \\
\text { improvement } \\
\text { Compliance with customer } \\
\text { needs } \\
\text { Flexibility improvement }\end{array}$ & Customer satisfaction & $\begin{array}{l}\text { Technological and } \\
\text { process integration, } \\
\text { cooperation }\end{array}$ & $\begin{array}{l}\text { Lack of willingness to } \\
\text { cooperate (at the supply } \\
\text { chain level) } \\
\text { Lack of appropriate, } \\
\text { common thinking } \\
\text { Lack of an integrated } \\
\text { communication protocol } \\
\text { Lack of standards: } \\
\text { technology and } \\
\text { processes }\end{array}$ \\
\hline
\end{tabular}

Source: adapted from [24].

\subsection{Sample}

The aim of the research was to explore how CEOs and other chief executive officers $(n=302)$ in Hungary, Romania, Serbia, and Slovakia perceive the main driving forces, barriers, and the role of stakeholders for the most common Industry 4.0 technologies. Our selection criteria were that survey participants should be representatives (members of the top management team) of financially and legally autonomous business enterprises. Scholars of leadership theory (e.g., [84]) recognized a long time ago that the management of an enterprise is typically a shared activity, extending beyond the chief executive. In most organizations, a small group has the potential to affect the form or fate of the enterprise [85]. The executives' self-assessment reports are commonly used in social sciences, especially in marketing and strategic management research [86,87]. We used a non-random approach for data collection, which is common in survey-based studies when respondents must be familiar with the studied phenomenon in order to increase the representativeness of the collected data $[88,89]$. To this end, we conducted targeted, personal inquiries in 2019. Respondents were allowed to discuss each question with the interviewer in the case more clarification was needed. The data collection includes 78 Hungarian, 118 Serbian, 77 Slovak and 29 Romanian-a total of 302 corporate queries. Of the companies, 72 are registered in the capital city of the country, while 173 are registered in other cities, and 55 in smaller settlements.

The research variables are in connection with both the companies and the individuals. The former are described by their name, industry in which their largest revenue is generated, their best-selling product/product line, year of establishment, number of employees and relative innovativeness. Individuals are described by the following variables: the respondents' gender, functional background, work experience in years, role at the company, how long they have been working for that company and how long they have been working in that role at the company.

A quarter of companies employ more than 250 people, $36 \%$ employ $50-249$ people, $29 \%$ employ 10-49 people, and $10 \%$ employ up to 9 people. It is important to note here that companies active in Industry 4.0 can be not only manufacturing companies, but also companies that supply them, such as engineering offices, robotics companies, or IT companies. The general information about the sample companies is shown in Table 2. 
Table 2. General information about the sample companies.

\begin{tabular}{ccc}
\hline Attribute & Average & Median \\
\hline Number of employees & 608 & 80 \\
\hline Operating revenue (EUR) & $136,251,984$ & $4,583,729$ \\
\hline Age of the company (years) & 25 & 22 \\
\hline
\end{tabular}

Seventy-six percent of respondents are male and $24 \%$ are female. The largest group of respondents were the CEOs/founders of companies (32\%), while the number of responses from sales and marketing was also significant (26\%). In addition, there were production managers $(19 \%)$, finance managers $(10 \%)$, product development managers $(9 \%)$ and logistics managers $(4 \%)$ among the respondents. Statistics on respondents' work experience are presented in Table 3. It is important to note here that although respondents have 20 years of work experience, the most common case is that they have been in their current role for 1 year.

Table 3. Work experience among respondents.

\begin{tabular}{cccc}
\hline Attribute & Average & Median & Mode \\
\hline Work experience & 19.04 & 19 & 20 \\
\hline Working in that company (years) & 11.5 & 10 & 3 \\
\hline $\begin{array}{c}\text { Working in that particular role } \\
\text { within that company (years) }\end{array}$ & 8.09 & 5 & 1 \\
\hline
\end{tabular}

\section{Results}

\subsection{Assessing the Innovative Behavior of Companies}

Industry 4.0 is a novel area in itself, and accordingly, respondents rated their company as fundamentally innovative compared to the industry average (Table 4). However, the responses also show that not all companies active in Industry 4.0 can be considered equally innovative, and that there are some differences between countries. In this respect, it should be emphasized that the most common answer in the Hungarian sample was $100 \%$, which means they considered their company to be extremely innovative.

Table 4. Assessing the innovative behavior of companies among respondents (\%).

\begin{tabular}{cccc}
\hline Sample & Average & Median & Mode \\
\hline Whole sample & 72.74 & 80 & 80 \\
\hline Hungary & 76.40 & 100 & 80 \\
\hline Serbia & 70.58 & 80 & 80 \\
\hline Slovakia & 73.45 & 80 & 80 \\
\hline Romania & 65.74 & 80 & 70
\end{tabular}

Note: 0 means less innovative than the industry average, while 100 means highly innovative.

\subsection{Most Important Areas of Industry 4.0 in Companies}

Respondents were asked to mark up to three focus areas for Industry 4.0 based on their company's practice. Based on the responses, automation of production processes (234 responses) is the most common focus area, followed by digitization (177) and the Internet of Things (96) (Figure 1). Other responses included standardization of processes, development of new technological processes, robotics, maintenance, packaging, world-class innovation, online application, and logistics. 


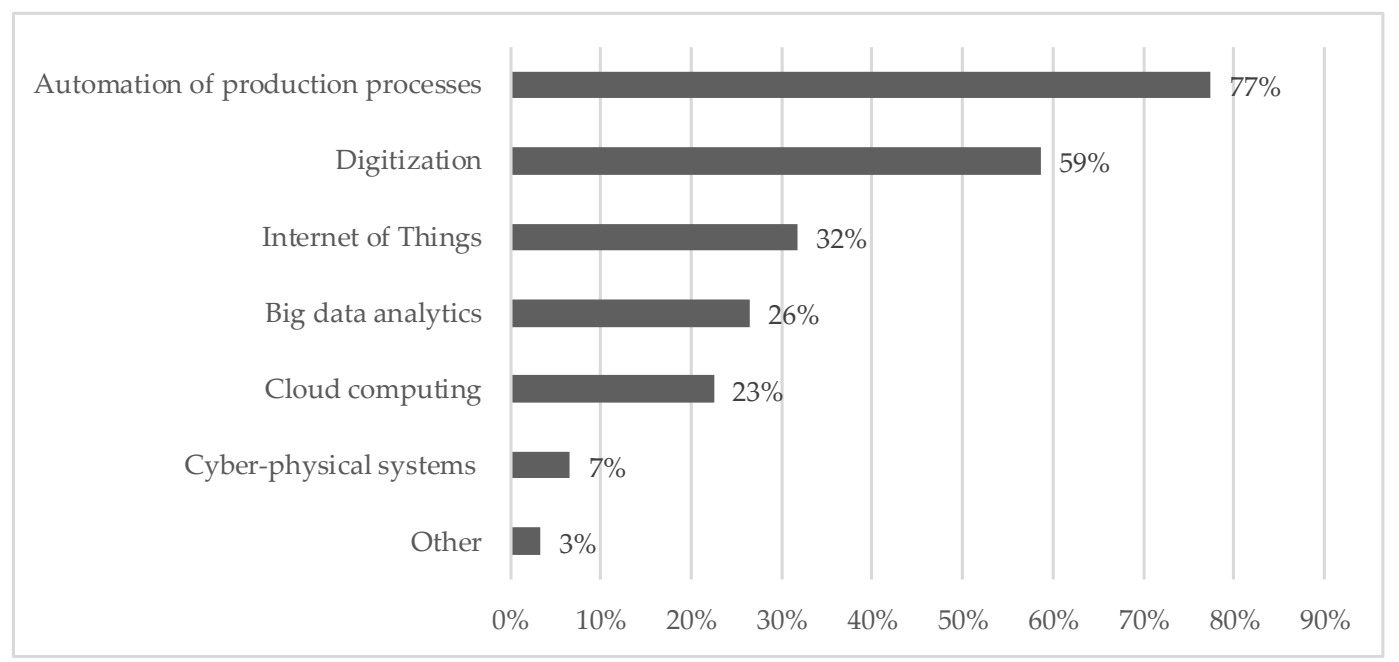

Figure 1. Industry 4.0 focus areas in the sample companies.

There is no significant relationship between the firm size and the Industry 4.0 focus areas; however, each focus area differs in part from country to country (Table 5). In Hungary, the general focus is less on general digitization compared to Serbia, and on the automation of production processes compared to the other three countries studied. Big data analytics are a more important focus area in Romania than in the other three countries. A less important focus area in Slovakia is cloud computing compared to Hungary and Serbia.

Table 5. Industry 4.0 focus areas by country.

\begin{tabular}{|c|c|c|c|c|c|c|}
\hline \multicolumn{7}{|c|}{ Firm Group Means $^{a}$} \\
\hline Focus Area & $\begin{array}{c}\mathrm{HU} \\
(n=78)\end{array}$ & $\begin{array}{c}\text { SRB } \\
(n=118)\end{array}$ & $\begin{array}{c}S K \\
(n=77)\end{array}$ & $\begin{array}{c}R O \\
(n=29)\end{array}$ & $\begin{array}{c}\text { Univariate } \\
F \text {-Value }\end{array}$ & $\begin{array}{c}\text { Scheffe } \\
\text { Multiple } \\
\text { Comparison b }\end{array}$ \\
\hline Digitization & 0.47 & 0.69 & 0.60 & 0.41 & $4.599 * *$ & $\mathrm{SRB}>\mathrm{HU}$ \\
\hline Internet of Things & 0.21 & 0.25 & 0.22 & 0.41 & 1.802 & \\
\hline Cyber-physical systems & 0.06 & 0.06 & 0.10 & 0.00 & 1.306 & \\
\hline $\begin{array}{l}\text { Automation of production } \\
\text { processes }\end{array}$ & 0.53 & 0.84 & 0.91 & 0.90 & $15.944^{* *}$ & $\begin{array}{l}\mathrm{SRB}>\mathrm{HU} \\
\mathrm{SK}>\mathrm{HU} \\
\mathrm{RO}>\mathrm{HU}\end{array}$ \\
\hline Cloud computing & 0.27 & 0.32 & 0.04 & 0.24 & $7.924^{* *}$ & $\begin{array}{l}\mathrm{HU}>\mathrm{SK} ; \\
\mathrm{SRB}>\mathrm{SK}\end{array}$ \\
\hline Big data analytics & 0.23 & 0.24 & 0.25 & 0.55 & $4.536^{* *}$ & $\begin{array}{l}\mathrm{RO}>\mathrm{HU} \\
\mathrm{RO}>\mathrm{SRB} \\
\mathrm{RO}>\mathrm{SK}\end{array}$ \\
\hline
\end{tabular}

${ }^{\mathrm{a}}$ Dichotomous variable 0 (no) and 1 (yes); ${ }^{\mathrm{b}}$ post-hoc analysis of differences $(p \leq 0.05)$, where HU = Hungary; $\mathrm{SRB}=$ Serbia; $\mathrm{SK}=$ Slovakia; and RO $=$ Romania; ${ }^{* *} p \leq 0.01$.

\subsection{Driving Forces of Industry 4.0}

Based on the distribution of the individual bipolar semantic statements, a ranking can be set (Figure 2 and Table 6). The more important an item is, the higher it is in the rankings. Each main category has five items. The value of the category is derived from the sum of the ranking values of each item. The lower the total category value, the higher it is in the rankings. Based on these, the following order can be set among the driving forces of Industry 4.0:

1. customer satisfaction;

2. productivity and efficiency;

3. financial resources and profitability;

4. management expectations;

5. human resources;

6. market conditions and competitors. 


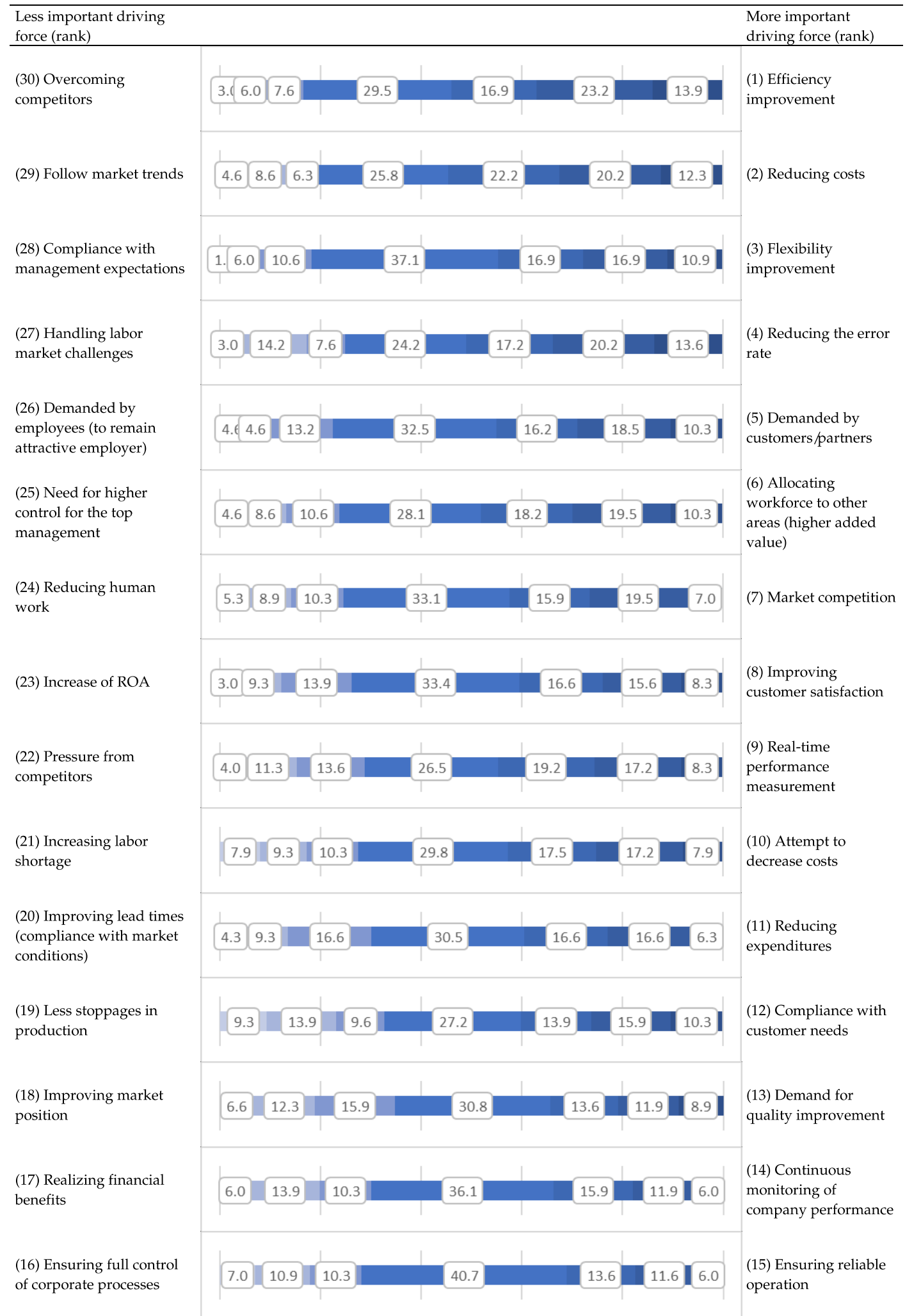

Figure 2. More and less important driving forces of Industry 4.0. 
Table 6. The most important driving forces of Industry 4.0.

\begin{tabular}{cccccccc}
\hline \multicolumn{1}{c}{ Ranks } \\
\hline Driving Force & Item1 & Item2 & Item3 & Item4 & Item5 & SUM & Final Rank \\
\hline Human resources & 6 & 21 & 24 & 26 & 27 & 104 & 5. \\
Financial resources and profitability & 2 & 10 & 11 & 17 & 23 & 63 & 3. \\
Market conditions and competitors & 7 & 18 & 22 & 29 & 30 & 106 & 6. \\
Management expectations & 9 & 14 & 16 & 25 & 28 & 92 & 4. \\
Productivity and efficiency & 1 & 4 & 15 & 19 & 20 & 59 & 2. \\
Customer satisfaction & 3 & 5 & 8 & 12 & 13 & 41 & 1. \\
\hline
\end{tabular}

\subsection{Barriers of Industry 4.0}

Exactly the same methodological procedure as for drivers, described in the section above, was applied for barriers (Figure 3 and Table 7). Based on these, the following order can be set among the barriers of Industry 4.0:

1. human resources;

2. financial resources and profitability;

3. technological and process integration, cooperation;

4. management reality;

5. organizational factors.

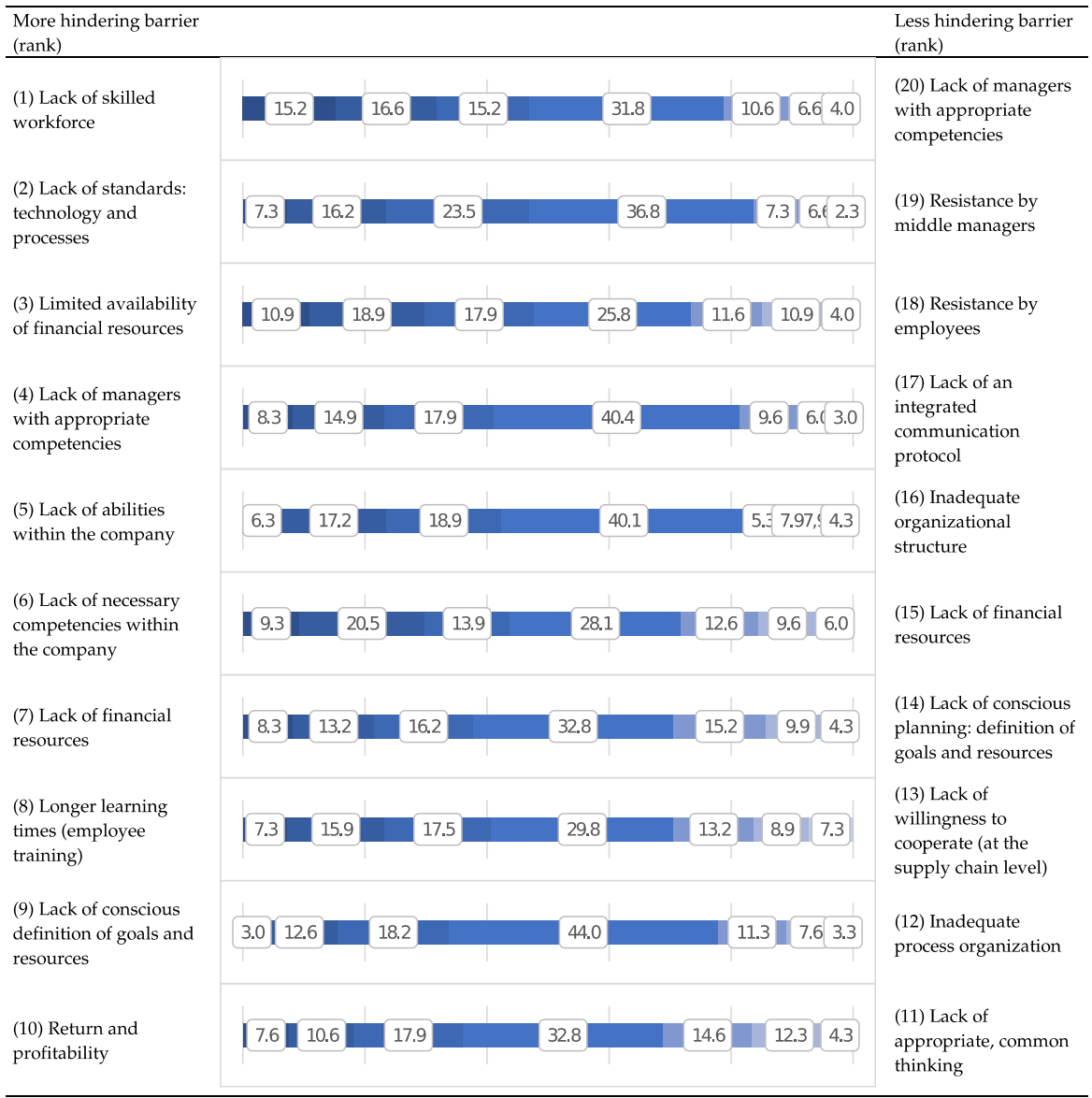

Figure 3. More and less hindering barriers of Industry 4.0. 
Table 7. The most hindering barriers of Industry 4.0.

\begin{tabular}{ccccccc}
\hline \multicolumn{2}{c}{ Ranks } & & & & & \\
\hline Barrier & Item1 & Item2 & Item 3 & Item4 & SUM & Final Rank \\
\hline Human resources & 1 & 5 & 6 & 8 & 20 & 1. \\
Financial resources and profitability & 3 & 7 & 10 & 15 & 35 & 2. \\
Management reality & 4 & 9 & 14 & 20 & 47 & 4. \\
Organizational factors & 12 & 16 & 18 & 19 & 65 & 5. \\
Technological and process integration, cooperation & 2 & 11 & 13 & 17 & 43 & 3. \\
\hline
\end{tabular}

\subsection{Expectations from Companies Active in the Field of Industry 4.0 for Support}

The research shows that the most important contribution on technological issues is expected mainly from universities and research sites (laboratories), and from suppliers of Industry 4.0 (test applications, solutions). In addition, even companies using Industry 4.0 can be important sources for addressing technological issues (demonstration plants/practices) (Table 8). In terms of financial resources, the surveyed companies rely on the government, and no financial resources are typically expected from other actors. In terms of human resources, the role of universities is paramount, but other actors also play an important role. There is also a significant expectation on the part of universities regarding management issues as well as on companies using Industry 4.0. In this respect, the role of Industry 4.0 suppliers and government is less significant (Table 8 ).

Table 8. Expectations from companies active in the field of Industry 4.0 for support.

\begin{tabular}{cccc}
\hline Technological Issues & $N$ & Average $^{\mathbf{a}}$ & Std. Dev. \\
\hline Universities, research institutes & 290 & 4.34 & 0.98 \\
Suppliers of Industry 4.0 & 280 & 4.19 & 0.99 \\
Users of Industry 4.0 & 276 & 3.99 & 1.12 \\
Government & 270 & 3.62 & 1.29 \\
\hline Financial resources & & & \\
\hline Government & 295 & 4.08 & 1.09 \\
Users of Industry 4.0 & 270 & 3.38 & 1.31 \\
Suppliers of Industry 4.0 & 267 & 3.34 & 1.29 \\
Universities, research institutes & 265 & 2.99 & 1.44 \\
\hline Human resources & & & \\
\hline Universities, research institutes & 283 & 4.05 & 1.17 \\
Users of Industry 4.0 & 275 & 3.76 & 1.27 \\
Government & 276 & 3.73 & 1.25 \\
Suppliers of Industry 4.0 & 273 & 3.62 & \\
\hline Management, leadership issues & & & 1.13 \\
\hline Users of Industry 4.0 & 284 & 3.89 & 1.20 \\
Universities, research institutes & 275 & 3.85 & 1.34 \\
Suppliers of Industry 4.0 & 276 & 3.71 & \\
Government & 268 & 3.42 & \\
\hline
\end{tabular}

a 5 point scale where $1=$ strongly disagree, $5=$ strongly agree.

\section{Discussion}

The first important finding of the applied research is that companies active in Industry 4.0 are not implementing all the technologies at once. A selective approach has been practiced. Their focus is first on automation of production, which is in line with other findings [15]. For example, Ref. [90] reports findings that suggest that technologies with the highest impact on competitiveness were those that encompassed the automatization of production processes by using machining lines, cooperating machines or individual machines at independent workplaces. This is followed by digitalization, with 
more than a half of the investigated companies focusing on it. Despite the evident necessity, all of the other technologies, such as big data analytics, are employed only by one-third or one-fourth of the companies [91]. We believe that the reason for this selective implementation is the level of development and practical preparedness, i.e., the maturity of technologies to be applied. Ghobakhloo [92] found operations technology maturity to be a determinant of technology implementation.

While the automatization of production processes has been used for decades, with new trends just improving the existing intensive effort, cyber-physical systems are de facto in their very infancy in terms of practical corporate usage. Companies rather wait until a new Industry 4.0 technology matures enough to bring evident benefits $[45,93]$. Another plausible explanation is that firms are unable to acquire, build and implement all the digital technologies at once. A potential reason for this is the financial burden, as well as the lack of capabilities and human resources. Consequently, firms may follow an incremental approach, and thus replacing their resources and processes in a modular fashion.

This paper supports the abovementioned findings, as demonstrated in Table 5. Namely, despite the differences between countries, the average levels are more or less similar. It means that even the most progressive firms implement digital transformation gradually, most likely in stages, as suggested by Mittal and his co-authors [94].

Comparing focus areas on a country level reveals a pattern of specialization, where countries assume a leading position in a few technologies, but fall behind other countries in other technologies on a statistically significant level.

Regarding the second research question, the most important driving forces for Industry 4.0 implementation are customer/client-related (improving customer satisfaction, customer-demanded quality improvement, compliance with customer needs), followed by internal drivers: increase in productivity, efficiency, as well as profitability. Human resource-related factors have not been perceived as a significant driving force. On the contrary, they are significant barriers. Improving market position and pressures from competitors were also perceived as relatively less important compared to the other factors. This could be regarded as a contradictory result, even in the case of B2B firms. Such firms are typically part of a value chain and it is quite often the case that firms from the CEE region take up lower value-added jobs. In this regard, they may perceive their position as either secured-as a member of the value chain with a long history of cooperation—or they may consider their outputs as standard with infrequent need for upgrades.

A relatively small number of companies in the analyzed countries are de facto implementing digital transformation. This is in line with the conclusion brought by Kane and his colleagues [95] that clear opportunities and challenges perceived by industrial manufacturers lead to slow and reluctant implementation of Industry 4.0. The slow, incremental approach could be a warning sign for policymakers, since a country's competitiveness largely depends on its companies engaging with pioneering advanced technologies.

Regarding Industry 4.0 barriers, human-related factors (i.e., lack of required skills, competences, and abilities) rank the highest on the list. Previous results are in line with the underlying assumption in the literature that the skills gap decelerates the implementation of the emerging technologies.

There are, however, certain exceptions. Basl's [45] study conducted on Czech firms reveals that only $12.5 \%$ of the firms perceive insufficient skills and training as an important barrier, showing at the same time that little awareness and the unclear benefits of Industry 4.0, along with high costs of implementation play the biggest role. Driving forces and motivational factors exhibit more resemblance to this research. However, these findings are based on a notably smaller sample ( 25 respondents), while the level of achieved digital transformation in the sample companies remains unclear. The results reveal that scarcity and deficiency in human-related factors generate heavy burdens on one hand, but on the other hand, the availability of human resources does not drive the implementation. The reason behind it could be that digital transformation per se is perceived as risky. The companies seem to delay major commitments because financial stability is more important than availability of skilled personnel. Once they have the budget to implement a planned investment, that is when they consider whether 
they possess the needed human resources and that is when they confront the fact that the right skill set is actually missing.

The fact that our findings are consistent and in line with the majority of literature on human resource barriers to new technology implementation makes them even more significant in the Industry 4.0 context, contrary to prior expectations [96]. Other perceived barriers were financial constraints and issues related to profitability. The lack of standards regarding technology and processes, communication protocols and common thinking regarding the digital transformation of the company have also been perceived as an important barrier. The factors related to resistance to change that accompanies digital transformation have not been seen as important barriers. These findings indicate that even though managers with appropriate competences will inevitably succeed in the age of Industry 4.0, resistance within the organization hardly poses a threat. This is contradictory to prior findings [16,42,52], given that resistance coming from various levels of the company usually acts as a hurdle when it comes to significant organizational changes. The contradiction is resolved since, according to our research, the digital transformation happens in a rather slow and gradual manner, and hence there is enough time for the organization to adapt culturally and internalize working with the new technology. However, it is also likely that managers are not aware of their own limitations. This study, however, presents an opinion-based ranking of Industry 4.0 barriers. Kamble and his colleagues [97] used interpretive structural modeling and fuzzy matrix analysis to study the inter-relationship between the barriers for Industry 4.0 and thus provide a framework for context-related identification of key barriers. The analysis supporting the last research question revealed that companies active in Industry 4.0 have distinct expectations from different stakeholders. The role of the government is primarily perceived as that of a potential financial supporter, while in all other aspects, minimal support is expected. We could speculate that this low ranking, in terms of expectations, is caused by current governmental unpreparedness to provide any relevant help although Industry 4.0 was acknowledged in 2015 by European officials as a highly influencing trend [3].

Our results indicate that suppliers of Industry 4.0 somehow resigned from their expected leading position to mere technology providers unable to sufficiently help with managerial or human resource problems, and thus leaving their customers in situations where they are forced to rely on support from universities, research institutions and other users of Industry 4.0. The results for Serbia are an exception, i.e., respondents from Serbian companies place the highest importance on suppliers of Industry 4.0 [23].

The complexity of novel problems and other difficulties probably led to high cooperation with other Industry 4.0 users, placing them in the position of the second most important stakeholder in the ecosystem. Universities and research institutions positioned themselves as a leading force in terms of contribution to the companies. They are expected to provide various sorts of support other than financial. The reason for this could be not only their direct participation in the creation of these technologies, but also their prompt reaction to new educational demands generated by Industry 4.0 [59]. We could speculate that some stakeholders (government and suppliers) are currently unable to sufficiently provide the help expected, which leads to searching for help from other users of Industry 4.0 and universities.

Adamik and Nowicki [90] found that although companies operating in Poland are increasingly aware of the benefits of Industry 4.0, relatively few companies are engaged in its implementation. They argued that subcontractors of large organizations-the B2B firms-are more active since they are compelled to implement Industry 4.0 solutions together with other members of the value chain. Hence, collective learning and the possibility of acquiring and sharing knowledge on these solutions with other partners provide the impetus for implementation.

One must be aware that Industry 4.0 is in its infancy, where only a small fraction of companies have already actively started using these advanced technologies. In this process of evolution of many applied technologies, which are in fact kind of unique prototypes, help from highly qualified specialists is needed. Our results indicate that companies active in Industry 4.0 hope to find such specialists at 
research institutions and universities. We believe that this is a transient state and that as the evolution of Industry 4.0 continues the expected roles of other stakeholders will change towards higher importance, especially for suppliers of Industry 4.0.

\section{Conclusions}

Authors identified the following research gaps, namely (1) the research regarding the implementation of digital transformation is constrained in relevance for practice; (2) cross-country analysis of practices is rarely available; and (3) the context and relevance of the respondent's position in a value chain system is missing. These research gaps inspired our study to investigate how B2B firms implement their digital transformations, what are the drivers and challenges, and where do they turn for support?

The academic contribution and novelty of this paper is its empirical investigation on a sample of 302 B2B firms in Hungary, Romania, Serbia, and Slovakia. In these four countries, industry was the largest economic activity, which makes them steady contributors to the European gross value added according to a survey by Eurostat [98]. The selection criteria were that participants should be a member of the top management team of financially and legally autonomous business enterprises. Participants in our research are proficient and well-informed about digital transformation, and they could articulate their experiences and perceptions in a reflective manner.

Our findings reveal that digital transformation is inherently a non-linear organizational change process and is very much influenced by the position of the organization in the value chain. The value chain itself generates a pull for the member organizations-which is what top managers perceive as a customer driver-and then they start planning the demanded implementation. Consequently, they learn from other members of their value chain, and they trust universities and research organizations with advising them on the right technology and management practices. Governments are perceived as less supportive stakeholders, mainly because firms' preference is to share or minimize the financial risks associated with investments into advanced technologies. As a result, governments are expected to take an active role in providing financial resources. Human resources and shortages of skills are associated with critical barriers; nevertheless, the progress towards digital maturity requires the careful consideration of the socio-technical factors of the firms.

We believe our research extends current knowledge, since until today, a limited number of studies has utilized cross-country data. The authors believe that the used technique increased response rates and generated a statistically significant amount of data. The results are also informative for practitioners and policymakers. For the former, by providing a benchmark, they are invited to take part in the transformation process before it is too late. Regarding the latter, it is critical for governments and policymakers to address the implementation barriers and drivers properly, otherwise the European competitiveness is at risk of decline. European economies are interconnected, and if firms from the CEE region do not excel in digital transformation, that can have a devastating effect on the overall performance of the entire value chain.

The research has its limitations, which need to be emphasized. The conducted type of exploratory research bears inherent limitations, since it is based on subjectivity and human perception and the understanding of Industry 4.0. An attempt was made to overcome this limitation by surveying and interviewing the managers of the companies that achieved the highest level of digital transformation. Furthermore, it is not guaranteed that our list of potential driving forces and barriers is exhaustive. The survey was based on the thorough literature analysis of Industry 4.0 driving forces and barriers but cannot exclude the presence of other significant driving forces and barriers not mentioned in the survey. Hence, the validity of the conclusions is potentially limited by the bias caused by the exclusion of these factors. The authors believe that the relevance and validity of the obtained results could be improved by extending this research to a European level. 
Author Contributions: Conceptualization, R.Z.S., I.V.H., R.H., L.H., M.M., D.D.; design of questionnaire, L.H.; methodology, R.Z.S.; formal analysis, R.Z.S., L.H.; resources, I.V.H., R.H., L.H., data curation, R.Z.S., I.V.H., R.H., L.H., A.R., M.M., D.D.; writing—original draft preparation, I.V.H., R.H., L.H.; writing—review and editing, I.V.H., R.H., L.H.; visualization, R.Z.S.; project administration and funding, A.R. All authors have read and agreed to the published version of the manuscript.

Funding: This research received no external funding.

Acknowledgments: This research was supported by a grant from the Ministry of Education, Science, Research and Sport of the Slovak Republic VEGA č.1/0388/20: "IT Management in Enterprises in Slovakia: International Standards and Norms Versus Individual Business Processes".

Conflicts of Interest: The authors declare no conflict of interest.

\section{References}

1. Cedefop. Skill Shortages and Gaps in European Enterprises: Striking A Balance between Vocational Education and Training and the Labour Market; Cedefop reference series (No 102.); CEDEFOP, Ed.; Publications Office: Luxembourg, 2015. [CrossRef]

2. Cedefop. Skills Forecast Trends and Challenges to 2030; Publications Office: Luxembourg, 2018. [CrossRef]

3. European Commission. Available online: https://ec.europa.eu/growth/content/digital-transformation-europeanindustry-and-enterprises-\%E2\%80\%93-report-strategic-policy-forum_en (accessed on 15 September 2020).

4. Stock, T.; Obernaus, M.; Kunz, S.; Khol, H. Industry 4.0 as an enabler for sustainable development: A qualitative assessment of its ecological and social potential. Process Saf. Environ. Prot. 2018, 118, 254-267. [CrossRef]

5. Schmidt, R.; Möhring, M.; Härting, R.C.; Reichstein, C.; Neumaier, P.; Jozinović, P. Industry 4.0-potentials for creating smart products: Empirical research results. In Proceedings of the International Conference on Business Information Systems, Colorado Springs, CO, USA, 8-10 June 2015; Springer: Cham, Switzerland; pp. 16-27.

6. Yazdi, G.P.; Azizi, A.; Hashemipour, M. An empirical investigation of the relationship between overall equipment efficiency (OEE) and manufacturing sustainability in industry 4.0 with time study approach. Sustainability 2018, 10, 3031. [CrossRef]

7. Braccini, A.; Margherita, E. Exploring Organizational Sustainability of Industry 4.0 Under the Triple Bottom Line: The Case of a Manufacturing Company. Sustainability 2018, 11, 36. [CrossRef]

8. Pollak, A.; Hilarowicz, A.; Walczak, M.; Gasiorek, D. A Framework of Action for Implementation of Industry 4.0. an Empirically Based Research. Sustainability 2020, 12, 5789. [CrossRef]

9. Gadaleta, M.; Pellicciari, M.; Berselli, G. Optimization of the energy consumption of industrial robots for automatic code generation. Robot. Comput. Integr. Manuf. 2019, 57, 452-464. [CrossRef]

10. Chen, C.; Liu, Y.; Kumar, M.; Qin, J.; Ren, Y. Energy consumption modelling using deep learning embedded semi-supervised learning. Comput. Ind. Eng. 2019, 135, 757-765. [CrossRef]

11. Bonilla, S.; Silva, H.; Silva, M.T.D.; Gonçalves, R.F.; Sacomano, J. Industry 4.0 and Sustainability Implications: A Scenario-Based Analysis of the Impacts and Challenges. Sustainability 2018, 10, 3740. [CrossRef]

12. Gabriel, M.; Pessel, E. Industry 4.0 and sustainability impacts: Critical discussion of sustainability aspects with a special focus on future of work and ecological consequences. Int. J. Eng. 2016, 1, 131-136.

13. De Benedictis, L.; Tajoli, L. Economic Integration, Similarity and Convergence in Trade Structures. Empirika 2007, 34, 117-137. [CrossRef]

14. Backé, P.; Korhonen, I.; Ritzberger-Grünwald, D.; Solanko, L. A tribute to 30 years of transition in CESEE. Focus Eur. Econ. Integr. 2019, 19, 11-28.

15. Frank, A.G.; Dalenogare, L.S.; Ayala, N.F. Industry 4.0 technologies: Implementation patterns in manufacturing companies. Int. J. Prod. Econ. 2019, 210, 15-26. [CrossRef]

16. Nagy, J.; Oláh, J.; Erdei, E.; Máté, D.; Popp, J. The role and impact of industry 4.0 and the internet of things on the business strategy of the value chain-The case of Hungary. Sustainability 2018, 10, 3491. [CrossRef]

17. Xu, L.D.; Xu, E.L.; Li, L. Industry 4.0: State of the art and future trends. Int. J. Prod. Res. 2018, 56, $2941-2962$. [CrossRef]

18. Chiarello, F.; Trivelli, L.; Bonaccorsi, A.; Fantoni, G. Extracting and mapping Industry 4.0 technologies using Wikipedia. Comput. Ind. 2018, 100, 244-257. [CrossRef] 
19. Loonam, J.; Eaves, S.; Kumar, V.; Parry, G. Towards digital transformation: Lessons learned from traditional organizations. Strateg. Chang. 2018, 27, 101-109. [CrossRef]

20. Müller, J.M.; Kiel, D.; Voigt, K.I. What drives the implementation of Industry 4.0? The role of opportunities and challenges in the context of sustainability. Sustainability 2018, 10, 247. [CrossRef]

21. Ritter, T.; Pedersen, C.L. Digitisation capability and the digitalization of business models in businesstobusiness firms: Past, present, and future. Ind. Mark. Manag. 2020, 86, 180-190. [CrossRef]

22. Chirumalla, K.; Oghazi, P.; Parida, V. Social media engagement strategy: Investigation of marketing and R\&D interfaces in manufacturing industry. Ind. Mark. Manag. 2018, 74, 138-149.

23. Vuksanović Herceg, I.; Kuč, V.; Mijušković, V.M.; Herceg, T. Challenges and Driving Forces for Industry 4.0 Implementation. Sustainability 2020, 12, 4208. [CrossRef]

24. Horváth, D.; Szabó, R.Z. Driving forces and barriers of Industry 4.0: Do multinational and small and medium-sized companies have equal opportunities? Technol. Forecast. Soc. Chang. 2019, 146, 119-132. [CrossRef]

25. Lin, B.; Wu, W.; Song, M. Industry 4.0: Driving factors and impacts on firm's performance: An empirical study on China's manufacturing industry. Ann. Oper. Res. 2019, 1-21. [CrossRef]

26. Yüksel, H. An empirical evaluation of industry 4.0 applications of companies in Turkey: The case of a developing country. Technol. Soc. 2020, 63, 101364. [CrossRef]

27. Stentoft, J.; Jensen, K.W.; Philipsen, K.; Haug, A. Drivers and Barriers for Industry 4.0 Readiness and Practice: A SME Perspective with Empirical Evidence. In Proceedings of the 52nd Hawaii International Conference on System Sciences, Maui, HI, USA, 8-11 January 2019; HICSS Press: Hawaii, HI, USA, 2019; Volume 6, pp. 5155-5164.

28. Cañas, H.; Mula, J.; Campuzano-Bolarín, F. A General Outline of a Sustainable Supply Chain 4.0. Sustainability 2020, 12, 7978. [CrossRef]

29. Prause, G. Sustainable Business Models and Structures for Industry 4.0. J. Secur. Sustain. Issues 2015, 5, 159-169. [CrossRef]

30. Prause, G.; Atari, S. On sustainable production networks for Industry 4.0. Entrep. Sustain. Issues 2017, 4, 421-431. [CrossRef]

31. Hanley, T.; Daecher, A.; Cotteleer, M.; Sniderman, B. The Industry 4.0 Paradox. 2018. Available online: https: //www2.deloitte.com/us/en/insights/focus/industry-4-0/challenges-on-path-to-digital-transformation.

html\#: \{\}:text=The\%20Industry\%204.0\%20paradox\%20With\%20the \%20vast $\% 20$ opportunity, transformation \%2C\%20revealing\%20several\%20disconnects\%20between \%20strategy $\% 20$ and $\% 20$ actions (accessed on 10 October 2020).

32. Xu, L.D. The contribution of systems science to Industry 4.0. Syst. Res. Behav. Sci. 2020, 37, 618-631. [CrossRef]

33. Romanová, A.; Zahradník, P. IT Governance a Industry 4.0. In IT Governance a Jeho Vplyv Na Konkurencieschopnost' Podnikov v SR: Zbornik Vedeckých Statí; Vydavatel'stvo EKONÓM: Bratislava, Slovak, 2019.

34. Christensen, C.M. The Innovator's Dilemma: When New Technologies Cause Great Firms to Fail; Harvard Business Review Press: Boston, MA, USA, 2013.

35. Lasi, H.; Kemper, H.-G.; Fettke, P.; Feld, T.; Hoffmann, M. Industry 4.0. Bus. Inf. Syst. Eng. 2014, $239-242$. [CrossRef]

36. Kamble, S.S.; Gunasekaran, A.; Ghadge, A.; Raut, R. A performance measurement system for industry 4.0 enabled smart manufacturing system in SMMEs-A review and empirical investigation. Int. J. Prod. Econ. 2020, 229, 107853. [CrossRef]

37. Chauhan, C.; Sharma, A.; Singh, A. A SAP-LAP linkages framework for integrating Industry 4.0 and circular economy. Benchmark. Int. J. 2019. [CrossRef]

38. Edgar, T.F.; Pistikopoulos, E.N. Smart manufacturing and energy systems. Comput. Chem. Eng. 2018, 114, 130-144. [CrossRef]

39. Raj, A.; Dwivedi, G.; Sharma, A.; de Sousa Jabbour, A.B.L.; Rajak, S. Barriers to the adoption of industry 4.0 technologies in the manufacturing sector: An inter-country comparative perspective. Int. J. Prod. Econ. 2020, 224, 107546. [CrossRef] 
40. Arnold, C.; Veile, J.; Voigt, K.I. What Drives Industry 4.0 Adoption? An Examination of Technological, Organizational, and Environmental Determinants. In Proceedings of the International Association for Management of Technology (IAMOT) Conference, Birmingham, UK, 22-26 April 2018.

41. Erol, S.; Jäger, A.; Hold, P.; Ott, K.; Sihn, W. Tangible Industry 4.0: A scenario-based approach to learning for the future of production. Procedia CIRP 2016, 54, 13-18. [CrossRef]

42. Kiel, D.; Müller, J.M.; Arnold, C.; Voigt, K.I. Sustainable industrial value creation: Benefits and challenges of industry 4.0. Int. J. Innov. Manag. 2017, 21, 1740015. [CrossRef]

43. Müller, J.M.; Buliga, O.; Voigt, K.I. Fortune favors the prepared: How SMEs approach business model innovations in Industry 4.0. Technol. Forecast. Soc. Chang. 2018, 132, 2-17. [CrossRef]

44. Müller, J.; Dotzauer, V.; Voigt, K.I. Industry 4.0 and its impact on reshoring decisions of German manufacturing enterprises. In Supply Management Research-Advanced Studies in Supply Management, 1st ed.; Bode, C., Bogasczevsky, R., Eßig, M., Lash, R., Stölzle, W., Eds.; Springer Gabler: Wiesbaden, Germany, 2017; Volume 1, pp. 165-179.

45. Basl, J. Pilot study of readiness of Czech companies to implement the principles of Industry 4.0. Manag. Prod. Eng. Rev. 2017, 8. [CrossRef]

46. Matt, C.; Hess, T.; Benlian, A. Digital transformation strategies. Bus. Inform. Syst. Eng. 2015, 57, $339-343$. [CrossRef]

47. Industry 4.0 How to Navigate Digitization of the Manufacturing Sector. Available online: https://www.mckinsey.com/ \{\}/media/McKinsey/Business\%20Functions/Operations/Our\%20Insights/ Industry\%2040\%20How\%20to\%20navigate\%20digitization\%20of\%20the\%20manufacturing\%20sector/ Industry-40-How-to-navigate-digitization-of-the-manufacturing-sector.ashx (accessed on 5 October 2020).

48. Caviggioli, F.; Ughetto, E. A bibliometric analysis of the research dealing with the impact of additive manufacturing on industry, business and society. Int. J. Prod. Econ. 2019, 208, 254-268. [CrossRef]

49. Nicolescu, R.; Huth, M.; Radanliev, P.; De Roure, D. Mapping the values of IoT. J. Inf. Technol. 2018, 33, 345-360. [CrossRef]

50. Ossewaarde, M. Digital transformation and the renewal of social theory: Unpacking the new fraudulent myths and misplaced metaphors. Technol. Forecast. Soc. Chang. 2019, 146, 24-30. [CrossRef]

51. European Commission. Available online: https://ec.europa.eu/digital-single-market/en/europe-investingdigital-digital-europe-programme (accessed on 21 September 2020).

52. Bauer, W.; Hämmerle, M.; Schlund, S.; Vocke, C. Transforming to a hyper-connected society and economytowards an Industry 4.0. Procedia Manuf. 2015, 3, 417-424. [CrossRef]

53. Reischauer, G. Industry 4.0 as policy-driven discourse to institutionalize innovation systems in manufacturing. Technol. Forecast. Soc. Chang. 2018, 132, 26-33. [CrossRef]

54. Schuh, G.; Gartzen, T.; Rodenhauser, T.; Marks, A. Promoting Work-based Learning through industry 4.0. Procedia CIRP 2015, 32, 82-87. [CrossRef]

55. Coskun, S.; Kayıkcı, Y.; Gençay, E. Adapting Engineering Education to Industry 4.0 Vision. Technologies 2019, 7, 10. [CrossRef]

56. Bongomin, O.; Gilibrays Ocen, G.; Oyondi Nganyi, E.; Musinguzi, A.; Omara, T. Exponential Disruptive Technologies and the Required Skills of Industry 4.0. J. Eng. 2020, 2020, 4280156. Available online: https://www.hindawi.com/journals/je/2020/4280156/ (accessed on 10 October 2020).

57. Mourtzis, D. Development of Skills and Competences in Manufacturing Towards Education 4.0: A Teaching Factory Approach. In Lecture Notes in Mechanical Engineering, Proceedings of 3rd International Conference on the Industry 4.0 Model for Advanced Manufacturing, AMP 2018, Belgrade, Serbia, 5-7 June 2018; Springer: Cham, Switzerland, 2018.

58. Mourtzis, D.; Vlachou, E.; Dimitrakopoulos, G.; Zogopoulos, V. Cyber-Physical Systems and Education 4.0-The Teaching Factory 4.0 Concept. Procedia Manuf. 2018, 23, 129-134. [CrossRef]

59. Cantú-Ortiz, F.J.; Sánchez, N.G.; Garrido, L.; Terashima-Marin, H.; Brena, R.F. An artificial intelligence educational strategy for the digital transformation. Int. J. Interact. Des. Manuf. 2020. [CrossRef]

60. Schwab, K. The Global Competitiveness Report 2018. Available online: http://www3.weforum.org/docs/ GCR2018/05FullReport/TheGlobalCompetitivenessReport2018.pdf (accessed on 5 October 2020).

61. Liakh, O.; Spigarelli, F. Managing Corporate Sustainability and Responsibility Efficiently: A Review of Existing Literature on Business Groups and Networks. Sustainability 2020, 12, 7722. [CrossRef]

62. Burmeister, E.; Aitken, L.M. Sample size: How many is enough? Aust. Crit. Care 2012, 25, 271-274. [CrossRef] 
63. Garland, R. A comparison of three forms of the semantic differential. Mark. Bull. 1990, 1, 19-24.

64. Bonekamp, L.; Sure, M. Consequences of Industry 4.0 on human labor and work organization. J. Bus. Med. Psychol. 2015, 6, 33-40.

65. Oettmeier, K.; Hofmann, E. Additive manufacturing technology adoption: An empirical analysis of general and supply chain-related determinants. J. Bus. Econ. 2017, 87, 97-124. [CrossRef]

66. Agolla, J.E. Human capital in the smart manufacturing and industry 4.0 revolution. Dig. Transf. Smart Manuf. 2018, 2, 41-58. [CrossRef]

67. Intelligent Efficiency: Opportunities, Barriers and Solutions. Available online: https://www.aceee.org/sites/ default/files/publications/researchreports/e13j.pdf (accessed on 10 October 2020).

68. Benefits and Barriers of Smart Manufacturing. Available online: https://oaktrust.library.tamu.edu/handle/ 1969.1/152162 (accessed on 10 October 2020).

69. Brettel, M.; Friederichsen, N.; Keller, M.; Rosenberg, M. How virtualization, decentralization and network building change the manufacturing landscape: An Industry 4.0 Perspective. Int. J. Mech. Ind. Sci. Eng. 2014, 8, 37-44.

70. Vrchota, J.; Volek, T.; Novotná, M. Factors Introducing Industry 4.0 to SMES. Soc. Sci. 2019, 8, 130. [CrossRef]

71. Ansaria, F.; Erola, S.; Sihna, W. Rethinking Human-Machine Learning in Industry 4.0: How Does the Paradigm Shift Treat the Role of Human Learning? Educ. Train. 2018, 2351, 9789. [CrossRef]

72. Digitalisierung im Mittelstand. Available online: http://www.forschungsnetzwerk.at/downloadpub/ Digitalisierung-im-Mittelstand.pdf (accessed on 10 October 2020).

73. Industry 4.0: The Future of Productivity and Growth in Manufacturing Industries. Available online: https://www.bcg.com/publications/2015/engineered_products_project_business_industry_4_future_ productivity_growth_manufacturing_industries.aspx (accessed on 9 October 2020).

74. Stock, T.; Seliger, G. Opportunities of sustainable manufacturing in industry 4.0. Procedia CIRP 2016, 40, 536-541. [CrossRef]

75. Burmeister, C.; Lüttgens, D.; Piller, F.T. Business model innovation for Industrie 4.0: Why the "Industrial Internet" mandates a new perspective on innovation. Die Unternehm. 2016, 70, 124-152. [CrossRef]

76. Laudien, S.M.; Daxböck, B. Business model innovation processes of average market players: A qualitative-empirical analysis. RED Manag. 2017, 47, 420-430. [CrossRef]

77. Laudien, S.M.; Bouncken, R.; Pesch, R. Understanding the acceptance of digitalization-based business models: A qualitative-empirical analysis. Acad. Manag. Glob. Proc. 2018, 104. [CrossRef]

78. Ibarra, D.; Ganzarain, J.; Igartua, J.I. Business model innovation through Industry 4.0: A review. Procedia Manuf. 2018, 22, 4-10. [CrossRef]

79. Ślusarczyk, B. Industry 4.0: Are we ready? Pol. J. Manag. Stud. 2018, 17, 232-248. [CrossRef]

80. Industry 4.0: Building the Digital Enterprise. Available online: https://www.pwc.com/gx/en/ industries/industrial-manufacturing/publications/assets/pwc-building-digital-enterprise.pdf (accessed on 5 October 2020).

81. Manufacturing Work of the Future: Industry 4.0. Available online: https://www.produktionsarbeit.de/ content/dam/produktionsarbeit/de/documents/Management_Summary.pdf (accessed on 5 October 2020).

82. Seufert, S.; Meier, C. From eLearning to digital transformation: A framework and implications for L\&D. Int. J. Corp. Learn. 2016, 9, 27-33. [CrossRef]

83. Herrmann, C.; Schmidt, C.; Kurle, D.; Blume, S.; Thiede, S. Sustainability in manufacturing and factories of the future. Int. J. Precis. Eng. Manuf. Green Technol. 2014, 1, 283-292. [CrossRef]

84. Cyert, R.M.; March, J.G. A behavioral theory of the firm. In Organizational Behavior 2: Essential Theories of Process and Structure; Miner, J.B., Ed.; Prentice-Hall: Englewood Cliffs, NJ, USA, 1963; pp. 169-187.

85. Hambrick, D.C. Top Management Teams. In Handbook of Top Management Teams; Bournois, F., Duval-Hamel, J., Roussillon, S., Scaringella, J.L., Eds.; Palgrave Macmillan: London, UK, 2010; pp. 23-30. [CrossRef]

86. Warner, K.S.R.; Wäger, M. Building dynamic capabilities for digital transformation: An ongoing process of strategic renewal. Long Range Plan. 2018, 52, 326-349. [CrossRef]

87. Grinstein, A.; Goldman, A. Characterizing the technology firm: An exploratory study. Res. Policy 2006, 35, 121-143. [CrossRef]

88. Shah, R.; Ward, P. Defining and developing measures of lean production. J. Oper. Manag. 2007, 25, 785-805. [CrossRef] 
89. Tortorella, G.L.; Vergara, A.M.C.; Garza-Reyes, J.A.; Sawhney, R. Organizational learning paths based upon industry 4.0 adoption: An empirical study with Brazilian manufacturers. Int. J. Prod. Econ. 2020, 284-294. [CrossRef]

90. Adamik, A.; Nowicki, M. Preparedness of companies for digital transformation and creating a competitive advantage in the age of Industry 4.0. In Proceedings of the 12th International Conference on Business Excellence, Bucharest, Romania, 22-23 March 2018; 2018; Volume 12, pp. 10-24.

91. Bolek, V. Priemysel 4.0—Význam zberu dát v podnikoch. In Ekonomika, Financie A MAnažment Podniku XIII: Zborník Vedeckých Statí Pri Príležitosti Týždňa Vedy a Techniky; Vydavatel'stvo EKONÓM: Bratislava, Slovak, 2019.

92. Ghobakhloo, M. Determinants of information and digital technology implementation for smart manufacturing. Int. J. Prod. Res. 2020, 58, 2384-2405. [CrossRef]

93. Dalenogare, L.S.; Benitez, G.B.; Ayala, N.F.; Frank, A.G. The expected contribution of Industry 4.0 technologies for industrial performance. Int. J. Prod. Econ. 2018, 204, 383-394. [CrossRef]

94. Mittal, S.; Khan, M.A.; Romero, D.; Wuest, T.; Mittal, S. A critical review of smart manufacturing \& Industry 4.0 maturity models: Implications for small and medium-sized enterprises (SMEs). J. Manuf. Syst. 2018, 49, 194-214. [CrossRef]

95. Kane, G.C.; Palmer, D.; Nguyen-Phillips, A.; Kiron, D.; Buckley, N. Achieving digital maturity. MIT Sloan Manag. Rev. 2017, 59, 1-11.

96. Benešová, A.; Tupa, J. Requirements for education and qualification of people in Industry 4.0. Procedia Manuf. 2017, 11, 2195-2202. [CrossRef]

97. Kamble, S.S.; Gunasekaran, A.; Sharma, R. Analysis of the driving and dependence power of barriers to adopt industry 4.0 in Indian manufacturing industry. Comput. Ind. 2018, 101, 107-119. [CrossRef]

98. Eurostat. Available online: https:/ec.europa.eu/eurostat/web/products-eurostat-news/-/DDN-20191028-2? inheritRedirect $=$ true\&redirect $=\% 2$ Feurostat $\% 2$ Fnews $\% 2$ Fwhats-new (accessed on 15 October 2020).

Publisher's Note: MDPI stays neutral with regard to jurisdictional claims in published maps and institutional affiliations.

(C) 2020 by the authors. Licensee MDPI, Basel, Switzerland. This article is an open access article distributed under the terms and conditions of the Creative Commons Attribution (CC BY) license (http://creativecommons.org/licenses/by/4.0/). 